\title{
(1) \\ BIOLOGICAL SCIENCES \\ Behavioral and morphological contrasts on the reproduction of two prolonged breeders of the genus Physalaemus (Anura: Leptodactylidae)
} (5ing

\author{
RODRIGO CAJADE, MIRTA L. GARCÍA, DIEGO O. DI PIETRO \& NÉSTOR G. BASSO
}

\begin{abstract}
The reproduction is one of the main events in the life of an organism, and anurans stand out among vertebrates because of the diversity of their reproductive strategies. We studied the reproduction of two syntopic species, Physalaemus aff. albonotatus and $P$. santafecinus, and comparatively described their reproductive activity pattern, advertisement calls, calling sites, daily calling activity, amplexus behavior, foam nests, and microhabitats in foam nests. In regards to the reproductive activity pattern, both species were defined as prolonged breeders. However, P. santafecinus exhibited a behavior like explosive breeders: it had a faster reproductive response against rains than P. aff. albonotatus. The calling activity was restricted exclusively to night hours in P. santafecinus, whereas $P$. aff. albonotatus called during both night and day. The advertisement calls of both species showed a rich harmonic structure, and were characterized by a bimodal harmonic dominance. The species differed significantly in microhabitat calling sites, foam nests, and microhabitats in foam nests. Namely, P. santafecinus frequently called and constructed its nests in sites more exposed than those of $P$. aff. albonotatus. The general differences in reproductive behaviors observed between the species principally agree with their different reproductive activity patterns.
\end{abstract}

Key words: Advertisement calls, calling activity, foam nest, frogs, oviposition nest sites, reproductive activity pattern.

\section{INTRODUCTION}

Anuran reproduction varies greatly in mating systems, oviposition modes, reproductive activity patterns, behaviors, fecundity, and development (Duellman \& Trueb 1994). Such diversification of reproductive strategies is exclusive among terrestrial vertebrates and has allowed anurans to colonize a wide variety of habitats around the world (Duellman \& Trueb 1994, Todd 2007, Gomez-Mestre et al. 2012). This varied strategies caught the attention of biologists, who have since described the reproductive biology of many anuran species, established basic patterns of reproduction (e.g. Crump 1974, Wells 1977, Basso 1990, Haddad \& Prado 2005), and provided new focuses to understand the diversity and evolution of anuran reproductive biology (Todd 2007, Gomez-Mestre et al. 2012, Zamudio et al. 2016).

With 48 species and multiples taxa, with unresolved taxonomy, the leptodactylid frogs of the genus Physalaemus exhibit a wide variation in the physiological, morphological, and behavioral traits of its reproductive strategies (Barrio 1965, Haddad \& Prado 2005, Lourenço et al. 2015, Frost 2018). Regarding the latitudinal range of its distribution, from north to south of South America, and from tropical to temperate climates, the reproductive biology of the Physalaemus species occurs under different environmental conditions. Therefore, the 
reproductive activity periods of the Physalaemus species also vary from those seen in special of tropical regions (capable of reproducing throughout the year) (e.g. P. crombiei; Pupin et al. 2010) and those seen in species with seasonal reproduction in subtropical and temperate regions, including some species of winter reproduction (e.g. P. henselii; Maneyro et al. 2008), to those seen in species with typically spring-summer reproduction (e.g. P. cf. biligonigerus; Prado et al. 2005). Mating systems include calling males, female choice, satellite males, advertisement calls, encounter calls, and aggressive calls associated territoriality and male-male fights (Wogel et al. 2002). Typically, in Physalaemus the eggs are laid in foam nest floating on ponds, and the exotrophic tadpoles develop in water in these ponds (Haddad \& Prado 2005). However, some species construct the foam nest on accumulated water on the axils of terrestrial bromeliads, or the humid floor forest, thus displaying two different reproductive modes (Haddad \& Pombal Jr. 1998, Haddad \& Prado 2005). Communal nests and communal oviposition were also described in many species of Physalaemus (Hödl 1990, Giaretta \& Menin 2004).

Physalaemus aff. albonotatus and $P$. santafecinus are two small leptodactilyds distributed in Argentina and Paraguay (Frost 2018). Physalaemus santafecinus is included in the P. biligonigerus species group (Lourenço et al. 2015), while $P$. aff. albonotatus is an undescribed taxon included in the P. cuvieri group (Lourenço et al. 2015). In Argentina, the distribution range of $P$. santafecinus and $P$. aff. albonotatus overlap in an extended area along the Parana River Basin in the provinces of Corrientes, Chaco, and Santa Fe. Although some aspects of the reproduction of $P$. aff. albonotatus is known (Barrio 1965, Zaracho et al. 2005, Schaefer \& Kehr 2010), this knowledge is incomplete. In this species, the advertisement call description provided by Barrio (1965) is poorly descriptive, and only provides the harmonic structure, call duration, and dominant frequency; no other variables were analysed, and no mean values were presented. Besides, there is no description of the microhabitat of calling and nest sites. Meanwhile, other descriptions of reproduction are observations, such as data on foam nest and reproductive pattern (e.g. Zaracho et al. 2005, Schaefer \& Kehr 2010). Even less is known about the reproductive biology of $P$. santafecinus. Its advertisement call has been described only in the same basic manner as that for $P$. aff. albonotatus (Barrio 1965), but some brief data on foam nests have been provided (Barrio 1967, Zaracho et al. 2005). However, the following remain unknown: the reproductive period, reproductive activity pattern, amplexus behavior, daily calling activity, and the microhabitats of calling and nest sites. In the province of Corrientes, both species are rather common during a great part of the year, and they are frequently found reproducing in the same water ponds after heavy rain ( $R$. Cajade, unpublished data). This scene provides an opportunity to study the reproductive biology of both species in a comparative context.

The main objective of this work is to provide a comparative description of the reproductive biology of both species, P. aff. albonotatus and $P$. santafecinus, focusing on reproductive activity patterns, reproductive periods, daily calling times, advertisement calls, acoustic interactions, calling sites, amplexus behavior, and nest features. This complete information will provide a basis for future explanatory studies.

\section{MATERIALS AND METHODS}

\section{Study area}

Field work was carried outalong three years(20082011) at two water bodies, separated by $5 \mathrm{~km}$, in 
the surroundings of Corrientes city, Argentina. This area has patches of original vegetation, Schinopsis balansae "quebracho" forest, which has been extremely degraded by human activity and largely replaced by sclerophyllous forest. The mean annual temperature is $21.5^{\circ} \mathrm{C}$, and the mean annual precipitation is $1500 \mathrm{~mm}$; there is no pronounced dry season, although periods of rain shortages occur every four to six years (Carnevali 1994). The first water body $\left(27^{\circ}\right.$ $25^{\prime} 52.68^{\circ} \mathrm{S}$; $58^{\circ} 44^{\prime} 43.83^{\prime \prime}$ W; DATUM WGS84) is a temporary pond surrounded by grasses, and with an average width of $1 \mathrm{~m}$, length of $50 \mathrm{~m}$, and depth of $40 \mathrm{~cm}$. The second one $\left(27^{\circ} 28^{\prime}\right.$ $26.61^{\prime \prime} \mathrm{S}$; $58^{\circ} 43^{\prime} 35.38^{\prime \prime}$ W: DATUM WGS84) is a semi-permanent pond with an elliptic shape, an area of $150 \mathrm{~m} 2$, and a variable maximum water depth (between 60 and $90 \mathrm{~cm}$ ). Vegetation consists of grasses on the shore, and aquatic emergent plants and aquatic plants in the water. The following other species were also found in both water bodies: Boana raniceps, Pithecopus azurea, Pseudis platensis, Lysapsus limellum, Scinax acuminatus, S. fuscomarginatus, S. nasicus, S. squalirostris, Leptodactylus bufonius, L. chaquensis, L. elenae, L. latrans, Odontophrynus americanus, Pseudopaludiocla falcipes, P. boliviana, and Elachistocleis bicolor. The sampling procedures included a paired study of the reproduction of both species: we studied some reproductive aspects in one of the bodies of water, and other reproductive aspects in the other body of water (details are provided in the following subsections). We decided on this procedure by considering the phenology of each body of water, and which body was more suitable for each type of study.

\section{Reproductive activity patterns}

We conducted weekly censuses between April 2008 and April 2009 at the temporary pond, recording the number of calling males and foam nests of each Physalaemus species. We counted the calling males at the perimeter of the pond between 21:00 and 23:00, by applying and combining the Visual Encounter Survey and Transects of Auditory Bands (Heyer et al. 1994). At the following day of each census, between 8:00 and 12:00, we counted the number of foam nests constructed the night before, which were distinguishable from older nests by their more compact structure. We recognized the foam nests of each species by the different color of eggs (brownish in P. santafecinus Barrio 1967; unpigmented in P. aff. albonotatus Barrio 1965). We used the data collected from the census to graphically represent the monthly abundance of nests and calling males to define and describe the annual reproductive periods of both species.

\section{Microhabitats of calling sites}

Between 15 and 18 October 2008, we described 50 calling sites of males for each species at the semi-permanent pond. We measured the water depth and the light incidence at each calling site. Light incidence was used as a measure of the hiding of calling males. We marked the calling sites during the night with a labelled stake, and the next day we measured water depth and light incidence at noon, placing a lux meter sensor 2 $\mathrm{cm}$ above the surface of the water at the exact site marked.

\section{Daily calling activity}

For five successive days during the spring of 2008, we made ambient recordings at the temporary pond to describe the daily calling activity pattern of each species. We took $5 \mathrm{~min}$ recordings every hour for the total of five days. We used an Audio-Technica ${ }^{\circledR}$ ATR55 microphone set in ambient function, and a Marantz PMD 660 digital recorder. We placed the equipment on a tripod directed towards the pond, and 1 $\mathrm{m}$ above the ground. Additionally, we recorded 
the incidence of light in the environment and the typical microhabitat used as the calling site for each species; this provided a variable directly influenced by the time that could act as an ambient condition when comparing the daily calling activity of both species. The daily calling activity pattern was described based on the presence/absence of calling males of each species registered in the audio recordings.

\section{Advertisement call descriptions}

The advertisement calls of 24 P. aff. albonotatus and 36 P. santafecinus males were recorded between spring 2009 and autumn 2010 at the semi-permanent pond (the equipment used is mentioned in the previous section). We held the microphone approximately $60 \mathrm{~cm}$ above water/ ground and $1 \mathrm{~m}$ away from a calling male. We made 2 min recordings for each male, and then measured the water temperature. We analyzed five advertisements per male (Tarano 2001). Recordings were analyzed with ADOBE AUDITION 1.0 software at a sample rate of $44100 \mathrm{~Hz}$, and 16 bit resolution. Frequency information was obtained through fast Fourier transformation (width 2408 points) using the Blackman-Harris window function. The sonograms, oscillograms, and power spectrum were produced with Raven Lite 4.0. Nine call traits (Table I) were considered, following Tarano (2001). Finally, we describe a call interaction between species recorded during field work.

\section{Amplexus behavior}

The amplexus was described based on field observations. Dates for nests and nest site descriptions were recorded during the census to describe the reproductive activity pattern (see above for details). Nests built the night before were selected. We considered five variables: light incidence, water depth, distance to an anchorage structure, nest volume, and the number of eggs. Light incidence was measured to describe the degree of nest concealment. Light incidence was measured using a digital lux meter MASTECH ${ }^{\circledR}$ M56610 (CE X10-100). Metric variables, such as water depth and distance to an anchorage structure, were measured with a metric ruler. The nest volumes were measured by putting them into $200 \mathrm{~mm}^{3}$ test tubes, and

Table I. Mean, standard deviation, and maximum and minimum values of $P$. aff. albonotatus and $P$. santafecinus call traits, (n) sample size.

\begin{tabular}{|c|c|c|c|c|}
\hline \multirow{2}{*}{ Call trait } & \multicolumn{2}{|c|}{ P. aff. albonotatus } & \multicolumn{2}{c|}{ P. santafecinus } \\
\cline { 2 - 5 } & Mean \pm SD (n) & Max - Min & Mean \pm SD (n) & Max - Min \\
\hline Call length (ms) & $1120 \pm 174(115)$ & $1541-821$ & $382 \pm 43(180)$ & $488-261$ \\
\hline Peak time (ms) & $681 \pm 168(115)$ & $1325-456$ & $265 \pm 36,6(180)$ & $373-195$ \\
\hline Call shape & $0.62 \pm 0.11(115)$ & $0.86-0.42$ & $0.69 \pm 0.08(180)$ & $0,86-0,51$ \\
\hline Call rate (calls/min) & $11 \pm 2.67(115)$ & $18-7$ & $51 \pm 8.18(180)$ & $65-36$ \\
\hline Intercall interval (s) & $5.9 \pm 1.63(115)$ & $10.8-2.7$ & $1.14 \pm 0.19(180)$ & $3,1-0,7$ \\
\hline Dominant frequency (Hz) & $3188 \pm 264(115)$ & $3656-2718$ & $2037 \pm 141(180)$ & $2343-1781$ \\
\hline Initial frequency dominant harmonic (Hz) & $4231 \pm 224(95)$ & $4641-3833$ & $3510 \pm 214(125)$ & $4052-3018$ \\
\hline Final frequency dominant harmonic (Hz) & $2775 \pm 200(95)$ & $3120-2166$ & $1897 \pm 125(125)$ & $2080-1784$ \\
\hline Frequency modulation (Hz) & $1406 \pm 105(95)$ & $1704-1077$ & $1546 \pm 247(180)$ & $2067-846$ \\
\hline
\end{tabular}


the number of eggs per nest was counted in the laboratory.

\section{Data analysis}

We made two multivariate analyses to evaluate differences between the two species in (1) calling site, by considering the two dependent variables measured (water depth and light incidence), and (2) the set of dependent variables derived from the microhabitats of nests (water depth, light incidence, and anchorage distance) and foam nests (volume and number of eggs). For each analysis, a biological matrix data was generated using the samples for each variable; from this matrix, a Bray-Curtis similarity matrix was constructed. One-factor (species) permutational multivariate analyses of variance (PERMANOVA) were made in each case to test the null hypotheses of no differences in the calling site variables and microhabitat nest set of variables (Anderson 2001). For each analysis, when significant differences were found, onefactor permutational univariate analyses of variance (ANOVA) were made from a Bray-Curtis dissimilarity matrix to test the null hypotheses of no differences among calling site variables and microhabitat nest variables. Data analyses were made using nontransformed data, and null hypotheses were constructed using unrestricted permutations of raw data. Each test was done using 4999 permutations (Anderson 2001). All analyses were made using PRIMER 6.1.13 and PERMANOVA + 1.0.3.

Spearman'srankcorrelationcoefficientswere used to show the relations between reproductive activity with rainfall and temperature, which allowed us to describe the activity patterns using XLSTAT 7.5. Daily rainfall and temperature were obtained from the meteorological station at the Centro de Información Meteorológica del Servicio Meteorologico Nacional, Comando de Regiones Aéreas de la Fuerza Aérea Argentina located at the study area. A Mann-Whitney U test was made to analyze differences in call variables during the call interaction described. All reported values are means \pm 1 SD ( $\min -$ max; $\mathrm{n})$.

\section{RESULTS}

\section{Reproductive activity pattern}

The reproductive periods of $P$. aff. albonotatus and $P$. santafecinus began simultaneously in early spring (28 September) 2008 and finished in summer 2009 (11 February for P. santafecinus, and 18 February for $P$. aff. albonotatus). During the reproductive period, both species had two sub-periods of reproductive activity observed at the two periods of greater precipitation (Fig. 1). The first sub-period was in spring (SeptemberNovember), and the second in summer (JanuaryFebruary). The number of nests was 113 for $P$. aff. albonotatus (first subperiod $=35$; second subperiod = 78; Fig. 1), and 318 for P. santafecinus (first subperiod = 224; second sub- period = 94; Fig. 1). The number of calling males was 564 for $P$. aff. albonotatus (first subperiod $=211$; second subperiod = 394; Fig. 1), and 561 for $P$. santafecinus (first sub-period $=364$; second sub-period $=$ 194; Fig. 1). In P. aff. albonotatus the maximum reproductive activity was concentrated during the second sub-period while in P. santafecinus this was observed during the first sub-period (Fig. 1). The number of calling males in P. aff. albonotatus was significantly and positively correlated with the precipitation that occurred one day before the census ( $n=34 ; r s=0.449 ; p$ $<0.001$ ); conversely, in P. santafecinus calling males were correlated with the precipitation that occurred on the day of the census ( $n=34$; $r s=0.426 ; p<0.01$ ). No significant relations were found between temperature and reproductive activity for either species. 


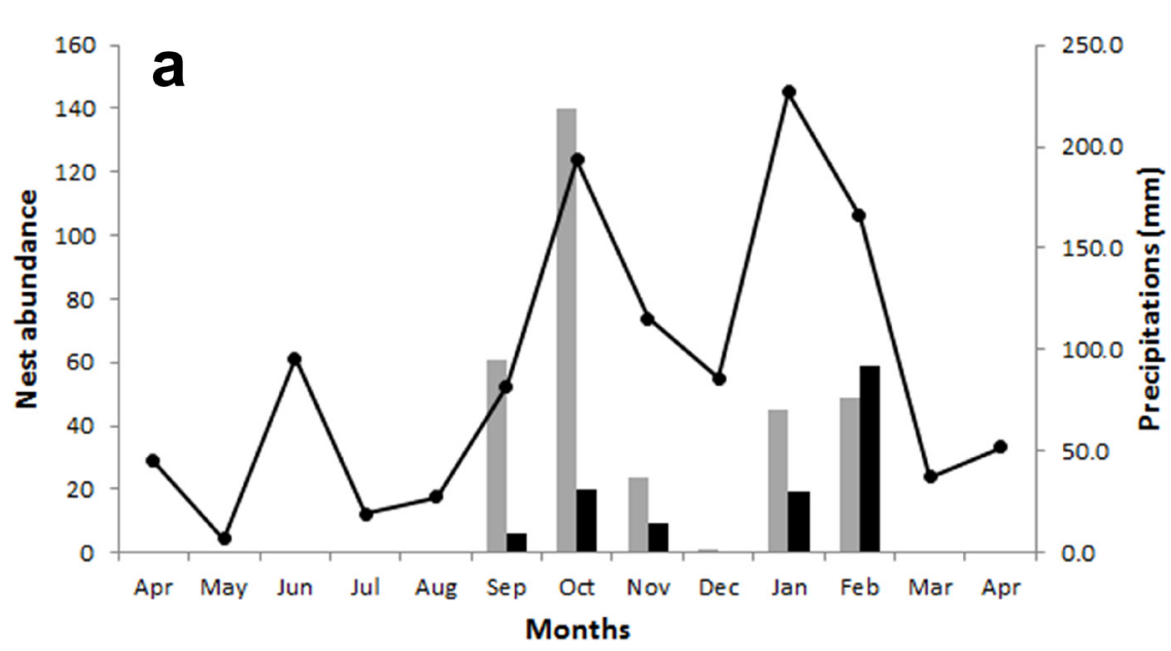

Figure 1. Annual reproductive activity of $P$. aff. albonotatus (black bars) and $P$. santafecinus (gray bars) based on (a) the monthly number of nests and ( $n$ ) the monthly number of calling males. Black lines indicate the monthly precipitation.

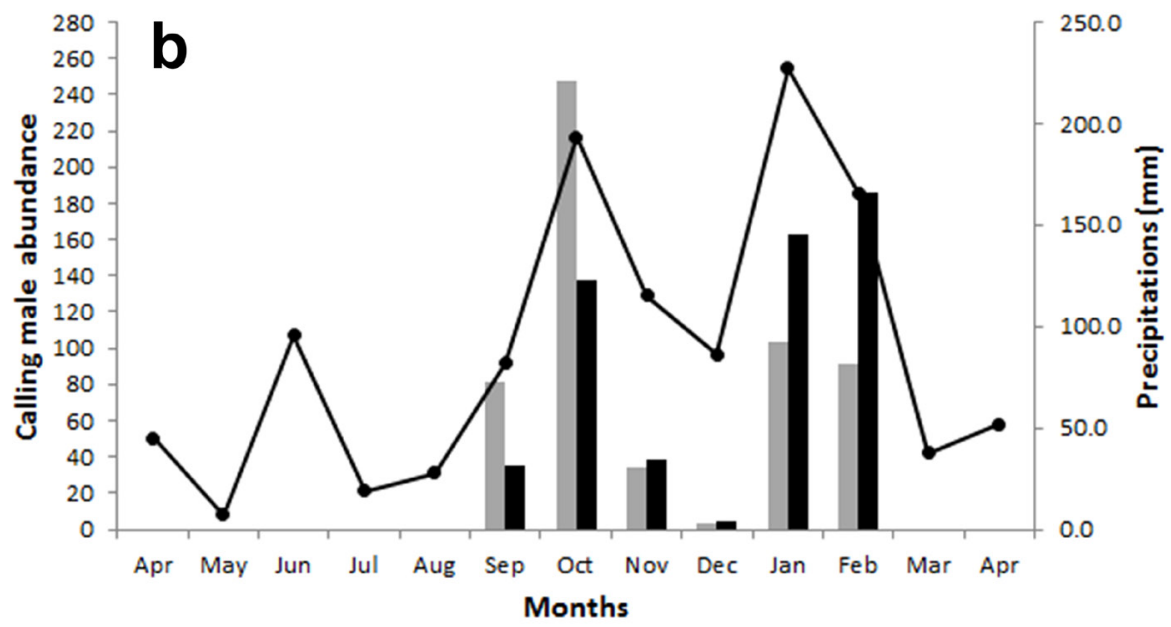

\section{Daily calling activity and calling sites}

The calling activity was recorded non-stop for the entire period of observation. For P. aff. albonotatus, we found a reduction of activity during daylight. In P. santafecinus, males began to vocalize immediately at dusk when the incidence of light decreased quickly to a mean of $4.2 \pm 4.39$ lux (1-12; 5) (Fig. 2). Calling activity was extended during the night, and began to decrease near dawn with the latest individuals calling at a mean light incidence of $24 \pm 4.47$ lux (19-27; 5); the calling fully stopped during the day.
The mean light incidence of the calling sites of $P$. aff. albonotatus and $P$. santafecinus was 251 $\pm 96.2 \operatorname{lux}(98-449 ; 50)$ and $461 \pm 94 \operatorname{lux}(249-619$; $50)$, respectively. Meanwhile, the mean water depth of the calling sites of $P$. aff. albonotatus and $P$. santafecinus was $4.6 \pm 1.38 \mathrm{~cm} \mathrm{(3-10;}$ $50)$ and $5.25 \pm 1.56 \mathrm{~cm}(3.5-13 ; 50)$, respectively. We observed a difference among calling sites between species (Table II): P. aff. albonotatus called under cover among the emergent vegetation (low light incidence) in shallow water, whereas $P$. santafecinus called exposed in sites with scarce emergent vegetation (high light incidence), and generally in deeper water. 


\section{Foam nest construction}

\section{Amplexus in water}

Amplexus outside water
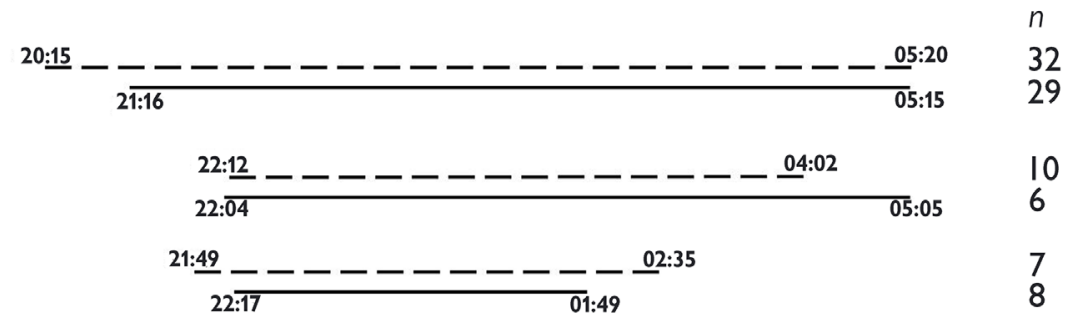

10

6

7

Calling activity
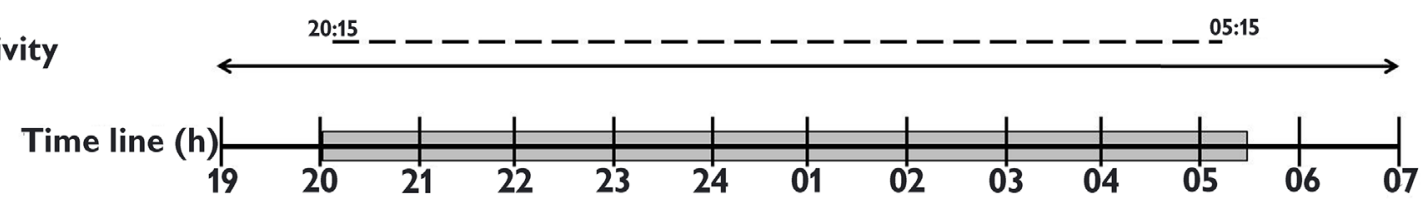

Figure 2. Timeline of the main behaviors of the reproductive activity of $P$. aff. albonotatus (continuous line) and $P$. santafecinus (intermittent line). The horizontal gray bar indicates night hours.

Table II. Permutational (a) MANOVA and (b) ANOVAs based on the Bray-Curtis similarities of the multivariate data on calling sites and microhabitat-nest variables from $P$. aff. albonotatus and $P$. santafecinus. The component of variation (CV) attributable to each source of variation is also shown.

\begin{tabular}{|c|c|c|c|c|c|c|c|}
\hline Source of variation & Source of analysis & Variables & $d f$ & MS & $F$ & $P$ & $\begin{array}{c}C V \\
\text { (\%) }\end{array}$ \\
\hline \multirow{3}{*}{ Species } & (a) Calling site & & 1 & 20163 & 181.69 & $<0.001$ & 19.79 \\
\hline & & (b) Water depth & 1 & 1165.9 & 7.90 & $<0.01$ & 4.51 \\
\hline & & (b) Light incidence & 1 & 20469 & 182.49 & $<0.001$ & 20.17 \\
\hline & (a) Microhabitat-nest & & 1 & 22234 & 76.41 & $<0.01$ & 25.73 \\
\hline & & (b) Water depth & 1 & 1023.4 & 1.34 & 0.240 & 2.81 \\
\hline & & (b) Light incidence & 1 & 15907 & 16.44 & $<0.01$ & 21.23 \\
\hline & & (b) Anchor distance & 1 & 19703 & 7.47 & $<0.001$ & 22.69 \\
\hline & & (b) Egg number & 1 & 20720 & 72.35 & $<0.001$ & 24.95 \\
\hline & & (b) Nest volume & 1 & 34274 & 122.45 & $<0.001$ & 32.02 \\
\hline
\end{tabular}

\section{Advertisement calls and call interactions}

The advertisement call of $P$. aff. albonotatus consisted of a long pure tone (whine-like) component, and had a harmonic structure and a marked decreasing frequency modulation (Fig. 3; Table I). An average call was 1120 ms long, and reached its maximum amplitude in $681 \mathrm{~ms}$, after which the amplitude declined gradually. As result, the amplitude modulation was smooth.
The mean number of harmonics was $6.2 \pm 0.4$ (6$7 ; n=120$ ). The fifth harmonic was the dominant one in most individuals ( $n=20$; visualized as the darkest harmonic in Fig. 3), while the fourth harmonic was dominant in the rest $(n=4)$. The mean dominant frequency was $3188 \mathrm{~Hz}$, which matches the fifth harmonic. The power spectrum of a fragmented call showed that the dominant frequency was not dominant throughout the 
call. In the first third of the call (370 ms), the first harmonic was dominant, showing a peak of energy at $843 \mathrm{~Hz}$; the fifth harmonic was dominant in the last two thirds, with peaks of energy at 3275 and $3093 \mathrm{~Hz}$, respectively (Fig. 4). The call rate was low, with a male emitting a mean 11 calls per minute. The mean water temperature during the call recordings was 29.5 $\pm 3.61^{\circ} \mathrm{C}\left(24.5-33^{\circ} \mathrm{C} ; \mathrm{n}=24\right)$.

In P. santafecinus, the advertisement call consisted of a short pure tone (whine-like) component, and had a harmonic structure and a strong decreasing frequency modulation (Fig. 3; Table I). An average call was 382 ms long, and reached its maximum amplitude in 265 ms, after which the amplitude declined brusquely. As result, the amplitude modulation was pronounced. The mean number of harmonics was $9 \pm 1(7-13 ; n=180)$. The sixth harmonic was dominant in most individuals $(n=25)$, while the fifth and fourth harmonics were dominant in seven and four individuals, respectively. The mean dominant frequency was at $2037 \mathrm{~Hz}$, which matches the sixth harmonic. The sixth harmonic was not dominant throughout the complete call. In the first two thirds, peaks of energy at 550 and $458 \mathrm{~Hz}$ corresponded to the first harmonic (Fig. 3 ). For the rest of the call, the sixth harmonic was dominant, showing peaks of energy at 2336 and $2153 \mathrm{~Hz}$ (Fig. 4). The call rate was high, with a male emitting a mean 51 calls per minute. The mean water temperature during the call recordings was $25.5 \pm 1.5^{\circ} \mathrm{C}$; $(24-29 ; n=36)$.

We observed and recorded a call interaction between a male of $P$. aff. albonotatus and two males of $P$. santafecinus vocalizing in duet. The interaction occurred near the shore of the semi-permanent pond, and the two males of $P$. santafecinus were about $10 \mathrm{~cm}$ away from the male of $P$. aff. albonotatus. The males of $P$. santafecinus emitted their call periodically until the male of $P$. aff. albonotatus called sporadically in the intercall interval of both $P$. santafecinus males (Video - Supplementary Material). When this occurred, the males of $P$. santafecinus significantly enlarged their intercall interval $(U=$ 17.50; $p=0.014 ; n=10$ ).
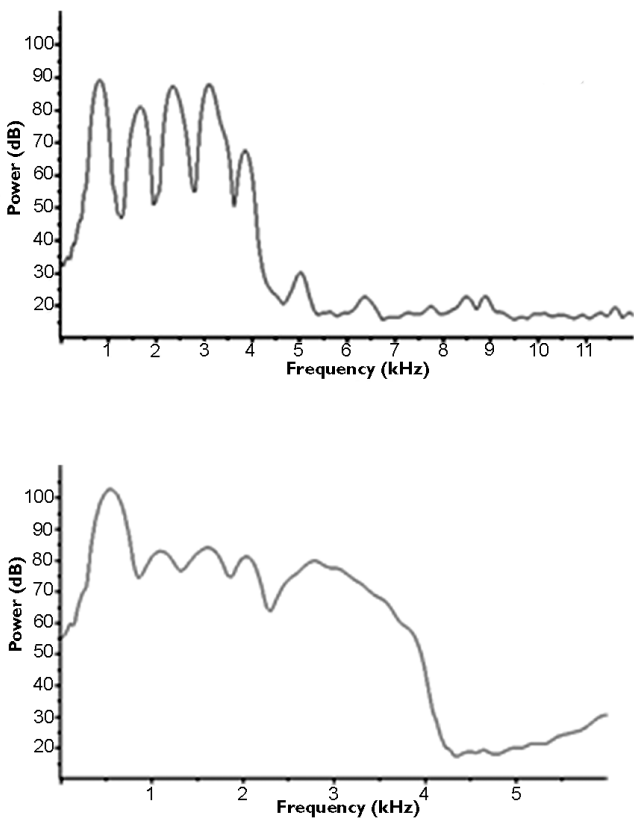
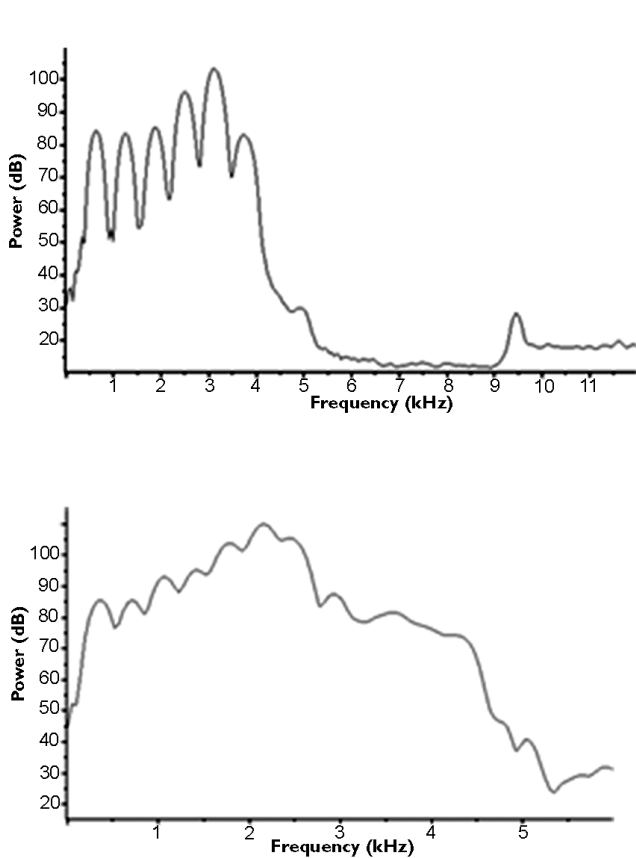

Figure 3. Advertisement calls of $P$. santafecinus (left) and $P$. aff. albonotatus (right) with spectrograms (upper), oscillograms (middle), and power spectrum (low). 

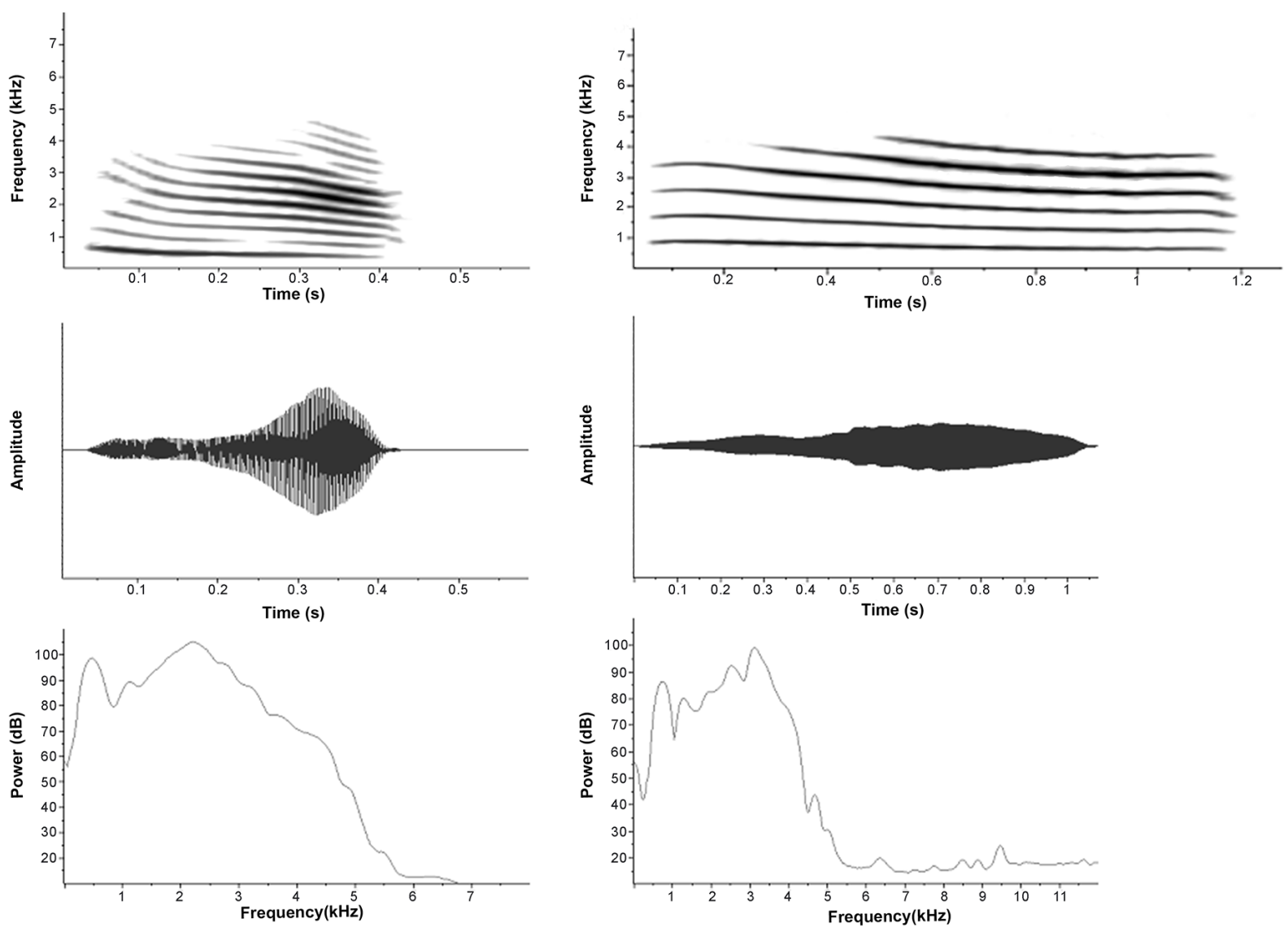

Figure 4. Power spectrum of the first third (left) and the final third (right) of an advertisement call of $P$. aff. albonotatus (above) and P. santafecinus (below).

\section{Amplexus, nests, and eggs}

In all the observations made, amplexus in both species occurred at the male calling site: $P$. albonotatus ( $n=6)$, P. santafecinus $(n=10)$. Our observations of $P$. santafecinus showed that when males detected a female they addressed their call to that female by body orientation towards it, and increased the call rate. When the female came within $3 \mathrm{~cm}$, the male engaged in amplexus in a quick movement. In P. aff. albonotatus, males showed a more passive attitude in front of females, without an increase in call emissions. The exact moment when amplexus was assumed was not observed in this species. Two types of amplexus activity were registered (Fig. 2). After to amplexus formation, the mating pair left the water to remain motionless on land (cases registered for both species) or above the water on emergent plants (only recorded in P. aff. albonotatus) (Figure S1 - Supplementary Material) until returning to the water for oviposition. Eggs of both species were laid in foam nests on the water surface (Figure S1). The foam nests had a half-sphere shape. Physalaemus aff. albonotatus eggs were unpigmented whereas $P$. santafecinus eggs were mildly pigmented and brownish. In both species, each mating pair constructed one foam nest; however, communal nests of two $(n=5)$, four $(n=3)$, five $(n=2)$, six $(n=2)$, and seven $(n=$ 2) nests were observed in $P$. aff. albonotatus, and communal nests of two $(n=4)$, three $(n=$ $2)$, five $(n=2)$, six $(n=2)$, thirteen $(n=2)$, and 
seventeen $(n=1)$ nests were observed in $P$. santafecinus (Figure S1). In $P$. santafecinus a communal nest resulted from two processes: communal oviposition, and the adhesion of a nest to another pre-existing nest (Figure S2). This last process was the only one recorded for P. aff. albonotatus. In two cases we observed an interspecific communal nest, with the nests identified by their sizes and the color of their eggs. The microhabitat and nest features of each species are summarized in Table III. We found differences between species in almost all variables measured (Table II). The nests of $P$. santafecinus were bigger, with a greater number of eggs, and were laid in more exposed microhabitats than those of $P$. albonotatus.

\section{DISCUSSION}

The reproductive periods of $P$. aff. albonotatus and $P$. santafecinus was extended in springsummer, which was associated with high precipitation and warm temperatures; this occurs in many species of the genus (Cardoso 1981, Haddad \& Pombal Jr. 1998, Wogel et al. 2002, Rodrigues et al. 2004, Giaretta \& Menin 2004, Brasileiro \& Martins 2006) and differs from those species of Physalaemus that reproduce in the cold season (Barrio 1964, Maneyro et al. 2008) or throughout the year (Pupin et al. 2010), or those that have a bimodal pattern throughout the year (Marangoni et al. 2012). The reproductive activity pattern of both Physalaemus species fits with the prolonged breeders definition (sensu Wells 1977), thus coinciding with previous observations for other species of the genus Physalaemus (Prado et al. 2005). However, the species showed differences in the phenology of their reproductive activity, both in the alternation of their sub-periods and peaks of annual activity as well as in their reproductive behavior. Correlation analyses showed immediate and intense reproductive activity in $P$. santafecinus in response to rainfall, while a retarded and gradual response was observed in $P$. aff. albonotatus. This was observed in $P$. santafecinus as intermittent reproductive activity during the reproductive period, and, like explosive breeders (Wells 1977), was concentrated intensely and exclusively during each precipitation event and the following three days. Besides the retarded response to precipitations, in $P$. aff. albonotatus the reproductive activity was extended gradually and continuously between each precipitation event. In conclusion, we can define $P$. aff. albonotatus as a "continuous prolonged breeder" species and $P$. santafecinus as an "intermittent prolonged breeder" species;

Table III. Foam nests and microhabitats of nest site characterization of $P$. aff. albonotatus and $P$. santafecinus. Average values $(*)$, standard deviation $( \pm)$, and minimum and maximum values () of the following variables are included: nest volume (V), egg number (Eg), water depth (Wd), anchorage distance (Ad), and light incidence (Li).

\begin{tabular}{|c|c|c|c|c|c|}
\hline Species & $\mathrm{V}\left(\mathrm{cm}^{3}\right)$ & En & $W d(\mathrm{~cm})$ & $\operatorname{Ad}(\mathrm{cm})$ & Li (lux) \\
\hline P. aff. albonotatus & $\begin{array}{c}\text { *32.15 } \\
\pm 11.91 \\
(16.3-55.9)\end{array}$ & $\begin{array}{c}* 473 \\
\pm 163 \\
(320-1163)\end{array}$ & $\begin{array}{c}\star 7.54 \\
\pm 4.11 \\
(1-21.6)\end{array}$ & $\begin{array}{c}* 4.98 \\
\pm 9.02 \\
(0.1-31)\end{array}$ & $\begin{array}{c}{ }^{*} 0.17 \\
\pm 1.23 \\
(0.03-0.54)\end{array}$ \\
\hline P. santafecinus & $\begin{array}{c}* 95.54 \\
\pm 36.62 \\
(37.3-230.5)\end{array}$ & $\begin{array}{c}* 1105 \\
\pm 492 \\
(461-3165)\end{array}$ & $\begin{array}{c}* 9.64 \\
\pm 6.91 \\
(4-36.5)\end{array}$ & $\begin{array}{c}* 25.60 \\
\pm 52.59 \\
(0.5-280)\end{array}$ & $\begin{array}{c}\star 0.43 \\
\pm 0.27 \\
(0.08-1)\end{array}$ \\
\hline
\end{tabular}


within the continuum between the extremes of prolonged and explosive breeders (Wells 1977).

The calling sites of $P$. aff. albonotatus and $P$. santafecinus fit within the little variation of calling site types described for the genus Physalaemus. Differences in calling sites were observed in the field and supported by the multivariate permutational analysis of variance (Table II). While P. aff. albonotatus used calling sites less exposed to light (with abundant emergent vegetation) and of shallow water, $P$. santafecinus used calling sites with higher light exposure (with little or no emergent vegetation) and of deeper water. Another paired comparison of calling sites in syntopic Physalaemus species was provided by Barrio (1964), who described different microhabitats of calling sites between $P$. henselii and P. fernandezae, and suggested the importance of differences in microhabitats of calling site as a reproductive isolating mechanism. Studies of anuran assemblages have pointed out that differences in calling sites have an important role in resource partitioning by reducing acoustic interference between species, and consequently increasing the transmission efficiency of the courtship signal (Drewry \& Rand 1983, Ptacek 1992). Although the variation in space resources (e.g. calling site) is usually interpreted as a consequence of speciesspecies interaction, it could also be due to other factors, such as environmental conditions, other biotic interactions (e.g. with predators), historical factors, and morphological attributes (Kopp \& Cabral-Eterovick 2006, Boquimpani-Freitas et al. 2007, Gorman \& Hass 2011). For example, some species exhibit a great plasticity in calling sites due to their morphological adaptations. This generally occurs in many hylids, in which adhesive discs provide the ability to climb different substrates (Pombal Jr. 1997). Conversely, leptodactylid frogs show a lower variation in calling sites (Kopp \& Cabral-Eterovick 2006). Our calling site description for P. aff. albonotatus and $P$. santafecinus, unvariables in type of substrates, agrees with the absence of morphological adaptations to climb, and with the observations made in other congeneric species, where a unique and defined type of microhabitat of calling site is generally described (Barrio 1965, Haddad \& Pombal Jr. 1998, Wogel et al. 2002).

Daily calling activity varied between both species of Physalaemus. While P. aff. albonotatus emitted its call throughout the day, P. santafecinus called exclusively at night. Complementary field observations over all three years of study support our analyses; we never registered a male of $P$. santafecinus calling at daylight hours, and $P$. aff. albonotatus was registered calling during both day and night. Daytime call activity was also recorded in other Physalaemus species, such as P. spiniger (Haddad \& Pombal 1998), P. riograndensis (Barrio 1965), P. fernandezae (Barrio 1964), and P. henselii (Barrio 1964), and P. signifer (Wogel et al. 2002). Some studies have described the assamblages structure made by the variation in daily calling activity (Boquimpani-Freitas et al. 2007). Other studies conducted at night hours hypothesised that differences in calling activity on an hourly time scale improves mating success and territorial defence by avoiding acoustic interference (Drewry \& Rand 1983, Garcia-Rutledge \& Narins 2001). Regarding mating success, the relation between calling activity at day hours with reproduction, such as the observation of amplexus or constructing a foam nest, has not been documented in the aforementioned Physalaemus species. We also never registered amplexus in $P$. aff. albonotatus during daylight hours. Moreover, we usually recorded encounter calls (Duellman \& Trueb 1994) between males of P. aff. albonotatus during daylight hours (R. Cajade, unpublished data). Without records of mating success, the 
advertisement call emitted during the day could have a territorial function, announcing the occupation of calling sites to be used for reproduction at night (Duellman \& Trueb 1994). The lower advertisement call emission during daylight hours observed in P. aff. albonotatus could be adequate for maintaining territory, minimizing the energy cost of repeated calls, and reducing exposure to predators ( $R$. Cajade, unpublished data). In conclusion, the activity of daily calls (both announcements and calls) of $P$. aff. albonotatus has a territorial role, own of prolonged breeders as this species. This behavior appears to be suitable, considering the typically great concentration of males of this species in reduced spaces (Duré et al. 2003). Additionally, the lack of encounter calls and calling activity during daylight hours in $P$. santafecinus agree with its classification as a type of explosive breeder.

The advertisement calls of $P$. aff. albonotatus and $P$. santafecinus showed the same general features seen in other Physalaemus species (Barrio 1965, Provete et al. 2012) and species of related genera (i.e. Engystomops see Tarano 2001, Ryan 1985). These calls are characterized by the emission of a simple "whine-like" component, none pulsated structure and reach in harmonics and frequency modulation. One of the most important features of the advertisement calls of $P$. aff. albonotatus and P. santafecinus is the variation in power energy distributed in different harmonics throughout the calls, thus defining a bimodal harmonic dominance. To our knowledge, until now, a variation in harmonic dominance has never been reported in the call descriptions for species of the genus Physalaemus (see Barrio 1965, Provete et al. 2012). In contrast, for species of related genera, fragmented analyses of advertisement calls showed no variation in harmonic dominance thorough the call, as in Engystomops pustulosus (Ryan 1985) or Engystomops enesefae (Tarano 2001). The variation in dominant frequency throughout the call exhibited by both Physalaemus species in the present study could have implications for interespecific call interactions, and represents a new direction to explore for calls in other Physalaemus species. During the call interaction analysed, the males of $P$. santafecinus prolonged and adjusted their intercall interval against the emission of calls from P. aff. albonotatus. The modification of calling behavior during an interspecific interaction has been described by other studies of paired species, and is considered a strategy to reduce acoustic interference (Littlejohn \& Martin 1969, Schwartz \& Wells 1983). Preliminary analyses showed that the bimodal harmonic dominance in both Physalaemus advertisement calls could optimize the call signals by providing a chance to reduce acoustic interference despite some degree of frequency overlap (R. Cajade, unpublished data).

Amplexus in $P$. aff. albonotatus and $P$. santafecinus occurred the same microhabitat as their advertisement call, coinciding with observations made for other species of the genus Physalaemus (Cardoso 1981, Hödl 1990, Wogel et al. 2002). The amplexus behavior observed in $P$. santafecinus was similar to that observed in $P$. centralis, where after a female approached the male (and came within $3 \mathrm{~cm}$ ) the male engaged the female in amplexus. However, the amplexus behavior differed from that of P. cuvieri (Barreto \& Andrade 1995) and P. ephippifer (Hödl 1990), in which pre-amplexus contact occurs between the male and female. This behavior in P. cuvieri and P. ephippifer is facultative, and therefore future observations of $P$. santafecinus should be able to determine if contact occurs before amplexus. The amplexus behavior of $P$. aff. albonotatus should be clarified. Moreover, the relation between the time of amplexus and the time of calling activity between each species supported the differences 
observed in reproductive activity patterns (Fig. 2). Unlike observations made in $P$. aff. albonotatus, the early construction of foam nests observed in $P$. santafecinus coincided with the species begins to call (Fig. 2), thus suggesting a reduced time for females to choose their mate; this is a trait of explosive breeders. Amplexus outside the water indicates that for these cases the foam nests would not be constructed at the same location where the amplexus occurs, and that the choice of oviposition site is an independent event for both species. The post-amplexus behavior of remaining motionless outside of the water has been reported in anuran species of other families, such as Hylidae (Toledo \& Haddad 2005), and in other species of Physalaemus, such as P. cuvieri (Cardoso 1981), P. centralis (Brasileiro \& Martins 2006), and P. ephippifer (Hödl 1990). This behavior could be a strategy to avoid intruder males or predators (Brasileiro \& Martins 2006) while the females takes time to ovulate before moving down to the water to spawn. During our study, several predation events by spiders, snakes, fish, and aquatic insects were recorded for $P$. aff. albonotatus and P. santafecinus, and foam nest construction was recorded at sites different from those for calling and amplexus.

Eggs laid in foam nests in aquatic environments, and producing exotrophic tadpoles as offspring, correspond to the eighth reproductive mode presented by Duellman \& Trueb (1994) and eleventh reproductive mode proposed by Haddad \& Prado (2005), which are the most common within the genus Physalaemus. These modes were observed in $P$. aff. albonotatus and $P$. santafecinus. The foam nest could be interpreted as an intermediate evolutionary step between eggs laid in water and those laid out of water, and could be considered as protection against predators (Heyer 1969, Downie 1988). The foam nest can also supply many adequate environmental conditions for egg development
(Haddad \& Prado 2005) and provide more resistance to insolation and desiccation (Downie 1988). Our results show significant differences between the microhabitat and nest features of the two Physalaemus species: the nests of $P$. santafecinus had more eggs, a higher volume, and were built at with greater light exposure and anchorage distance than those of $P$. aff. albonotatus. The choice of an appropriate nesting site may be an important component of the species' fitness and have a profound influence on the environmental conditions critical to embryo development and the phenotype of offspring (Resetartis \& Wilbur 1989, Resetartis 1996). We also observed differences in egg pigmentation between species (unpigmented in P. aff. albonotatus, but pigmented in P. santafecinus) and this agree with differences in sunlight incidence in oviposition microhabitat. Many leptodactylid frogs with unpigmented eggs have covered nest sites, whereas those with pigmented eggs have more exposed nest sites (Crump 1974). The pigmentation may serve to shield the embryos from ultraviolet radiation, thus providing a photoprotection (Blaustein \& Blend 2003, Perotti \& Diéguez 2006). Although this hypothesis has never been proved, the differences in foam nest sites between P. aff. albonotatus (low sunlight exposure) and $P$. santafecinus (high sunlight exposure) could be related to the differences in egg pigmentation, and thus reflect differences in adaptation to sunlight.

Communal nests were observed in $P$. aff. albonotatus and P. santafecinus. In anurans, the communal nests phenomenon has been reported in about 83 species of 11 families (Doddy et al. 2009). Within the genus Physalaemus, communal nests have been recorded in some species (P. ephippifer Hödl 1990; P. cuvieri Barreto \& Andrade 1995; P. marmoratus Giaretta \& Menin 2004). Since this behavior is facultative, several hypotheses have been postulated to explain its 
function, such as to reduce the chance of egg predation (Ryan 1985), reduce desiccation (Zina 2006), and reduce the cost of energy during foam nest construction (Flemming et al. 2009, Dalgetty \& Kennedy 2010) or its causality, such as being an artefact produced by the scarcity of optimal oviposition sites (Hödl 1990). Although, these hypotheses need to be tested in P. aff. albonotatus and $P$. santafecinus, the presence of communal oviposition in P. santafecinus and the absence of it in P. aff. albonotatus could be related to the differences in reproductive activity patterns registered for each species. The stronger response to precipitation observed in P. santafecinus could promote communal oviposition due to the great concentration of individuals per reproduction event. Furthermore, while both species studied showed different nest site microhabitats, some degree of superposition of microhabitat conditions took place. Giaretta \& Menin (2004) reported interspecies communal nests in other species of Physalaemus. In terms of resources use, the interspecific communal nests propose a trade-off in which the benefit of any of the functional hypotheses for communal nests is greater than the potential negative interactions implied by space overlap. However, despite the numerous reports of communal nests in Physalaemus, interespecific communal nests are scarce in the literature as well as in our study (only two records). Therefore, a causal hypothesis, such as the scarcity of optimal sites for foam nest construction (Hödl 1990), should be considered for these cases.

\section{Acknowledgments}

We thank Camila Falcione, Jose M. Piñiero, and Federico Marangoni (Universidad Nacional del Noredeste, Argentina) for field assistance, Dan Cogalniceanu and Florina Stanescu (Universitatea "Ovidius" din Constanţa, Romania) for critical comments on the early draft of the manuscript, and the Dirección de Recursos Naturales, Ministerio de Turismo de la Provincia de Corrientes,
Argentina, for study permits. This work was financially supported by Consejo Nacional de Investigaciones Científicas y Técnicas during Doctoral Thesis of Cajade R. (Tesis de Doctorado. Universidad Nacional de La Plata, Buenos Aires, Argentina. p. 164. Unpublished data citations).

\section{REFERENCES}

ANDERSON MJ. 2001. A new method for non-parametric multivariate analysis of variance. Austral Ecol 26: 32-46.

BARRETO L \& ANDRADE GV. 1995. Aspects of the reproductive biology of Physalaemus cuvieri (Anura: Leptodactylidae) in northeastern Brazil. Amphibia-Reptilia 16: 67-76.

BARRIO A. 1964. Relaciones morfológicas, Eto-Ecológicas y Zoogeográficas entre Physalaemus henselii (Peters) y P. fernandezae (Müller) Anura, Leptodactylidae). Act Zool Lill 20: 285-305.

BARRIO A. 1965. El género Physalaemus (Anura, Leptodactylidae) en Argentina. Physis 21: 421-448.

BARRIO A. 1967. Notas complementarias sobre el Genero Physalaemus Fitzinger (Anura: Leptodactylidae). Physis 74: 5-8.

BASSO NG. 1990. Estrategias adaptativas en una comunidad subtropical de anuros. Cuad Herpetol (Ser Monogr) 1: 1-71.

BLAUSTEIN AR \& BELDEN LK. 2003. Amphibian defenses against ultraviolet-B radiation. Evol Dev 5: 89-97.

BOQUIMPANI-FREITAS L, MARRA RV, VAN SLUYS M \& ROCHA CFD. 2007. Temporal niche of acoustic activity in anurans: interspecific and seasonal variation in a neotropical assemblage from south-eastern Brazil. Amphibia-Reptilia 28: 269-276.

BRASILEIRO CA \& MARTINS M. 2006. Breeding biology of Physalaemus centralis Bokermann, 1962 (Anura: Leptodactylidae) in southeastern Brazil. J Nat Hist 40: 1199-1209.

CARDOSO AJ. 1981. Biologia e sobrevivencia de Physalaemus cuvieri Fitz., 1826 (Amphibia, Anura), na natureza. Cien Cult 33: 1224-1228.

CARneVali R. 1994. Fitogeografía de la Provincia de Corrientes, 1st ed., Argentina: Gobierno de la Provincia de Corrientes e Instituto Nacional de Tecnología Agropecuaria, $324 \mathrm{p}$.

CRUMP ML. 1974. Reproductive strategies in a tropical anuran community. Misc Publ Mus Nat Hist Univ Kan 61: $1-68$. 
DALGETTY L \& KENNEDY MW. 2010. Building a home from foam-túngara frog foam nest architecture and threephase construction process. Biol Lett 6: 293-296.

DODDY JS, FREEDBERG S \& KEOGH JS. 2009. Communal egglaying in reptiles and amphibians: evolutionary patterns and hypotheses. Quart Rev Biol 84: 229-252.

DOWNIE JR. 1988. Functions of the foam-nesting Leptodactylid Physalaemus pustulosus. Herp Jour 1: 302-307.

DREWRY GE \& RAND S. 1983. Characteristics of an acoustic community: Puerto Rican frogs of the genus Eleutherodactylus. Copeia 1983: 941-953.

DUELLMAN WE \& TRUEB L. 1994. Biology of amphibians. The Johns Hopkins University Press. London (UK), 670 p.

DURÉ MI, SCHAEFER EF \& KEHR AI. 2003. Descripción del canto de encuentro en Physalaemus albonotatus (Anura: Leptodactylidae) de Corrientes, Argentina. Cuad Herpetol 17: 119-125.

FLEMMING RI, MACKENZIE CD, COOPER A \& KENNEDY MW. 2009. Foam nest components of the túngara frog: a cocktail of proteins conferring physical and biological resilience. Proc Biol Scien Roy Soc 276: 1787-1795.

FROST DR. 2018. Amphibian Species of the World: an Online Reference. Version 6.0 (Date of access, 29/10/2018). Electronic Database accessible at http://research.amnh. org/herpetology/amphibia/index.html. American Museum of Natural History, New York, USA.

GARCIA-RUTLEDGE EJ \& NARINS PM. 2001. Shared acoustic resources in an old world frog community. Herpetologica 57: 104-116.

GIARETTA AA \& MENIN M. 2004. Reproduction, phenology and mortality sources of a species of Physalaemus (Anura, Leptodactylidae). Jour Nat Hist 38: 1711-1722.

GOMEZ-MESTRE I, PYRON RA \& WIENS JJ. 2012. Phylogenetic analyses reveal unexpected patterns in the evolution of reproductive modes in frogs. Evolution 66: 3687-3700.

GORMAN TA \& HAAS CA. 2011. Seasonal microhabitat selection and use of syntopic populations of Lithobates okaloosae and Lithobates clamitans clamitans. J Herpetol 45: 313-318.

HADDAD CFB \& POMBAL JR JP. 1998. Redescription of Physalaemus spiniger (Anura: Leptodactylidae) and description of two new reproductive modes. J Herpetol 32: 557-565.

HADDAD CFB \& PRADO CPA. 2005. Reproductive modes in frogs and their unexpected diversity in the Atlantic forest of Brazil. Bioscience 55: 207-217.
HEYER WR, DONNELLY MA, MCDIARMID RW, HAYEK LAC \& FOSTER MS. 1994. Measuring and Monitoring Biological Diversity: Standard Methods for Amphibians. Smithsonian Institution Press. Washington DC, $384 \mathrm{p}$.

HEYER WR. 1969. The adaptative ecology of the species groups of the genus Leptodactylus (Amphibia, Leptodactylidae). Evolution 23: 421-428.

HÖDL W. 1990. An analysis of foam nest construction in the Neotropical frog Physalaemus ephippifer (Leptodactylidae). Copeia 1990: 547-554.

KOPP K \& CABRAL ETEROVICK P. 2006. Factors influencing spatial and temporal structure of frog assemblages at ponds in southeastern Brazil. Jour Nat Hist 40: 1813-1830.

LITTLEJOHN ML \& MARTIN AA. 1969. Acoustic interaction between two species of leptodactylid frogs. Anim Behav 17: 785-791.

LOURENÇO LB, TARGUETA CP, BALDO D, NASCIMENTO J, GARCIA PCA, ANDRADE GV, HADDAD CFB \& RECCO-PIMENTEL SM. 2015. Phylogeny of frogs from the genus Physalaemus (Anura, Leptodactylidae) inferred from mitochondrial and nuclear gene sequences. Mol Phylogenetics Evol 92: 204-216.

MANEYRO R, NÚÑEZ D, BORTEIRO C, TEDROS M \& KOLENC F. 2008. Mating call and female sexual cycle in Uruguayan populations of Physalaemus henselii (Anura, Leiuperidae). Iheringia Sér Zool 98: 210-214.

MARANGONI F, BARRASSO DA, CAJADE R \& AGOSTINI G. 2012. Body size, age and growth pattern of Physalaemus fernandezae (Anura: Leiuperidae) of Argentina. North-West J Zool 8: 63-71.

PEROTTI MG \& DIÉGUEZ MC. 2006. Effect of UV-B exposure on eggs and embryos of Patagonian anurans and evidence of photoprotection. Chemosphere 56: 2063-2070.

POMBAL JR JP. 1997. Distribuição espacial e temporal de anuros (Amphibia) em uma poça permanente na Serra de Paranapiacaba, sudeste do Brasil. Rev Bras Biol 57: 583-594.

PRADO CPA, UETANABARO M \& HADDAD CFB. 2005. Breeding activity patterns, reproductive modes, and habitat use by anurans (Amphibia) in a seasonal environment in the Pantanal, Brazil. Amphibia-Reptilia 26: 211-221.

PROVETE DB, GAREY MV, TOLEDO LF, NASCIMENTO J, LOURENÇO LB, DE CERQUEIRA ROSSA-FERES D \& HADDAD CFB. 2012. Redescription of Physalaemus barrioi (Anura: Leiuperidae). Copeia 2012: 507-518.

PTACEK MB. 1992. Calling sites used by male gray treefrogs, Hyla versicolor and Hyla chrysoscelis, in sympatry and allopatry in Missouri. Herpetologica 48: 373-382. 
PUPIN NC, GASPARINI JL, BASTOS RP, HADDAD CFB \& PRADO CPA. 2010. Reproductive biology of an endemic Physalaemus of the Brazilian Atlantic forest, and the trade-off between clutch and egg size in terrestrial breeders of the $P$. signifer group. Herpetol J 20: 147-156.

RESETARTIS WJ \& WILBUR HM JR. 1989. Choice of oviposition site by Hyla chrysoscelis: role of predators and competitors. Ecology 70: 220-228.

RESETARTIS WJ JR. 1996. Oviposition site choice and life history evolution. Amer Zool 36: 205-215.

RODRIGUES DJ, UETANABARO M \& LOPES FS. 2004. Reproductive strategies of Physalaemus nattereri (Steindachner, 1863) and P. albonotatus at Serra da Bodoquena, State of Mato Grosso do Sul, Brazil. Rev Esp Herpetol 18: 63-73.

RYAN MJ. 1985. The túngara frog. A study in sexual selection and communication. Chicago: Univ. of Chicago Press, 230 p.

SCHAEFER EF \& KEHR AI. 2010. Comportamiento reproductivo de Physalaemus albonotatus (Steindachner, 1864) (Anura, Leiuperidae) en el nordeste Argentino. Rev Esp Herpetol 24: 27-39.

SCHWARTZ JJ \& WELLS KD. 1983. An experimental study of acoustic interference between two species of of neotropical treefrogs. Anim Behav 31: 181-190.

TARANO Z. 2001. Variation in male advertisement calls in the neotropical frog Physalaemus enesefae. Copeia 2001: 1064-1072.

TODD BD. 2007. Parasites lost? An overlooked hypothesis for the evolution of alternative reproductive strategies in amphibians. Am Nat 179: 793-799.

WELLS KD. 1977. The social behaviour of anurans amphibians. Anim Behav 25: 666-693.

WOGEL E, ABRHUNOSA PA \& POMBAL JP JR. 2002. Atividade reprodutiva de Physalaemus signifer (Anura, Leptodactylidae) em ambiente temporário. Iheringia Ser Zool 92: 57-70.

ZAMUDIO KR, BELL RC, NALI RC, HADDAD CFB \& PRADO CPA. 2016. Polyandry, Predation, and the Evolution of Frog Reproductive Modes. Am Nat 188: 41-61.

ZARACHO VH, CÉSPEDEZ JA \& ÁlVAREZ BB. 2005. Aspectos Reproductivos de Anfibios de las provincias de Corrientes y Chaco, Argentina. Miscelanea 14: 417-426.

ZINA J. 2006. Communal nest in Physalaemus pustulosus (Amphibia: Leptodactylidae): experimental evidence for female oviposition preferences and protection against desiccation. Amphibia-Reptilia 27: 148-150.

\section{SUPPLEMENTARY MATERIAL}

Video

Figures S1 and S2.

\section{How to cite}

CAJADE R, GARCÍA ML, DI PIETRO DO \& BASSO NG. 2020. Behavioral and morphological contrasts on the reproduction of two prolonged breeders of the genus Physalaemus (Anura: Leptodactylidae). An Acad Bras Cienc 92: e20180773. DOI 10.1590/0001-3765202020180773.

Manuscript received on May 24, 2018;

accepted for publication on April 25, 2019

\section{RODRIGO CAJADE}

https://orcid.org/0000-0003-3614-2054

MIRTA L. GARCÍA ${ }^{2}$

https://orcid.org/0000-0003-0143-7397

\section{DIEGO O. DI PIETRO 3}

https://orcid.org/0000-0001-7329-6429

\section{NÉSTOR G. BASSO 4}

https://orcid.org/0000-0003-3345-5442

${ }^{1}$ Laboratorio de Herpetología, Facultad de Ciencias Exactas y Naturales y Agrimensura, Universidad Nacional del Nordeste y CONICET, Av. Libertad 5470, CP. 3400, Corrientes, Argentina

${ }^{2}$ Laboratorio de Ictiología, Facultad de Ciencias Naturales y Museo, Universidad Nacional de La Plata, 60 y 122, CP. 1900, La Plata, Buenos Aires, Argentina

${ }^{3}$ Sección Herpetología, División Zoología Vertebrados, Facultad de Ciencias Naturales y Museo, Universidad Nacional de La Plata, Av. 122 y 60 s/n, CP. 1900, La Plata, Buenos Aires, Argentina

${ }^{4}$ Instituto de Diversidad y Evolución Austral - CONICET, Bvd. Brown, 2915, CP. 9120, Puerto Madryn, Chubut, Argentina

Correspondence to: Rodrigo Cajade

E-mail: rodrigocajade@hotmail.com

\section{Author contributions}

RC obtained the data, analyzed and interpreted the results. MLG and NGB directed the research and provided financial support. DOD contributed to statistical analysis. RC wrote the manuscript with the contribution of all co-authors.

(c) $B Y$ 


\section{ERRATUM}

In the article Behavioral and morphological contrasts on the reproduction of two prolonged breeders of the genus Physalaemus (Anura: Leptodactylidae), with DOI number: http://doi.org/10.1590/00013765202020180773, published in the journal Anais da Academia Brasileira de Ciências, 92(Suppl. 2): e20180773.

\section{Page 1}

\section{Reads:}

DIEGO O. PIETRO

\section{Should read:}

DIEGO O. DI PIETRO

\section{Page 7}

\section{Reads:}

Table II. Permutational (a) MANOVA and (b) ANOVAs based on the Bray-Curtis similarities of the multivariate data on calling sites and microhabitat-nest variables from $P$. aff. albonotatus and $P$. santafecinus. The component of variation (CV) attributable to each source of variation is also shown.

\begin{tabular}{|c|c|c|c|c|c|c|c|}
\hline Source of variation & Source of analysis & Variables & $d f$ & MS & $\boldsymbol{F}$ & $\mathbf{P}$ & $\begin{array}{l}C V \\
(\%)\end{array}$ \\
\hline \multirow{3}{*}{ Species } & (a) Calling site & & 1 & 20163 & 181.69 & $<0.001$ & 19.79 \\
\hline & & (b) Water depth & 1 & 1165.9 & 7.90 & $<0.01$ & 4.51 \\
\hline & & (b) Light incidence & 1 & 20469 & 182.49 & $<0.001$ & 20.17 \\
\hline & (a) Microhabitat-nest & & 1 & 22234 & 76.41 & $<0.01$ & 25.73 \\
\hline & & (b) Water depth & 1 & 1023.4 & 1.34 & 0.240 & 2.81 \\
\hline & & (b) Light incidence & 1 & 15907 & 16.44 & $<0.01$ & 21.23 \\
\hline & & (b) Anchor distance & 1 & 19703 & 7.47 & $<0.001$ & 22.69 \\
\hline & & (b) Egg number & 1 & 20720 & 72.35 & $<0.001$ & 24.95 \\
\hline & & (b) Nest volume & 1 & 34274 & 122.45 & $<0.001$ & 32.02 \\
\hline
\end{tabular}




\section{Should read:}

Table II. Permutational (a) MANOVA and (b) ANOVAs based on the Bray-Curtis similarities of the multivariate data on calling sites and microhabitat-nest variables from $P$. aff. albonotatus and $P$. santafecinus. The component of variation (CV) attributable to each source of variation is also shown.

\begin{tabular}{|c|c|c|c|c|c|c|c|}
\hline Source of variation & Source of analysis & Variables & $d f$ & MS & $F$ & $\mathbf{P}$ & $\begin{array}{l}\text { CV } \\
(\%)\end{array}$ \\
\hline \multirow{9}{*}{ Species } & (a) Calling site & & 1 & 20163 & 181.69 & $<0.001$ & 19.79 \\
\hline & & (b) Water depth & 1 & 1165.9 & 7.90 & $<0.01$ & 4.51 \\
\hline & & (b) Light incidence & 1 & 20469 & 182.49 & $<0.001$ & 20.17 \\
\hline & (a) Microhabitat-nest & & 1 & 22234 & 76.41 & $<0.01$ & 25.73 \\
\hline & & (b) Water depth & 1 & 1023.4 & 1.34 & 0.240 & 2.81 \\
\hline & & (b) Light incidence & 1 & 15907 & 16.44 & $<0.01$ & 21.23 \\
\hline & & (b) Anchor distance & 1 & 19703 & 7.47 & $<0.001$ & 22.69 \\
\hline & & (b) Egg number & 1 & 20720 & 72.35 & $<0.001$ & 24.95 \\
\hline & & (b) Nest volume & 1 & 34274 & 122.45 & $<0.001$ & 32.02 \\
\hline
\end{tabular}

Page 8

Reads:
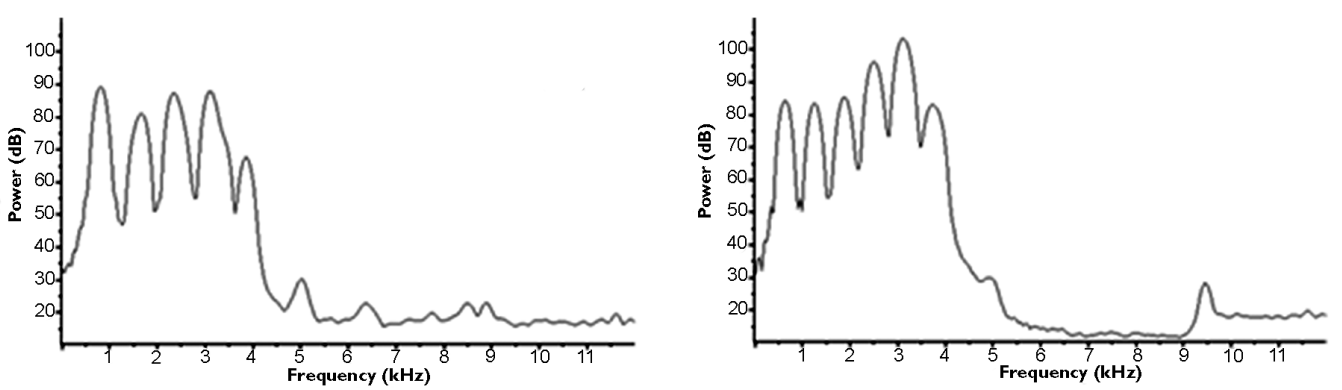

Figure 3.

Advertisement

calls of $P$.

santafecinus

(left) and $P$. aff.

albonotatus

(right) with

spectrograms

(upper),

oscillograms

(middle), and
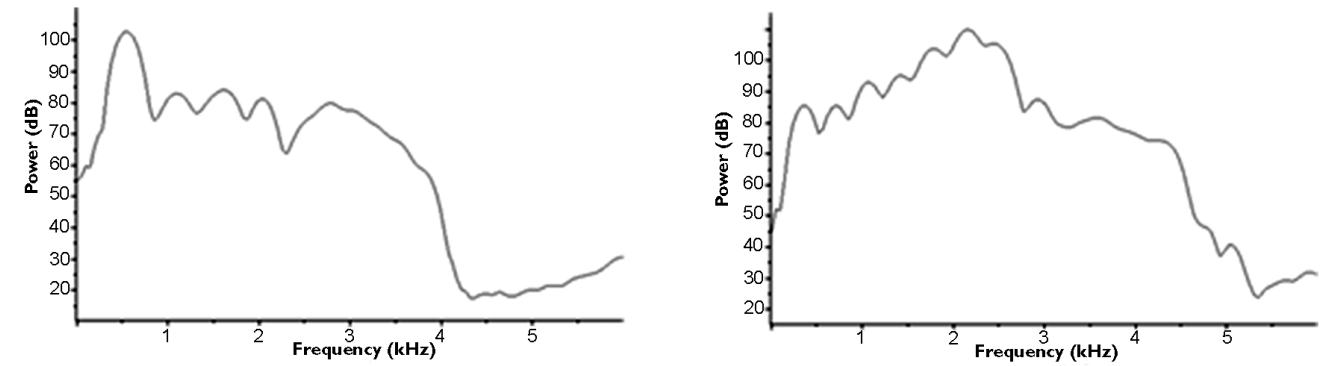

power spectrum (low). 


\section{Should read:}
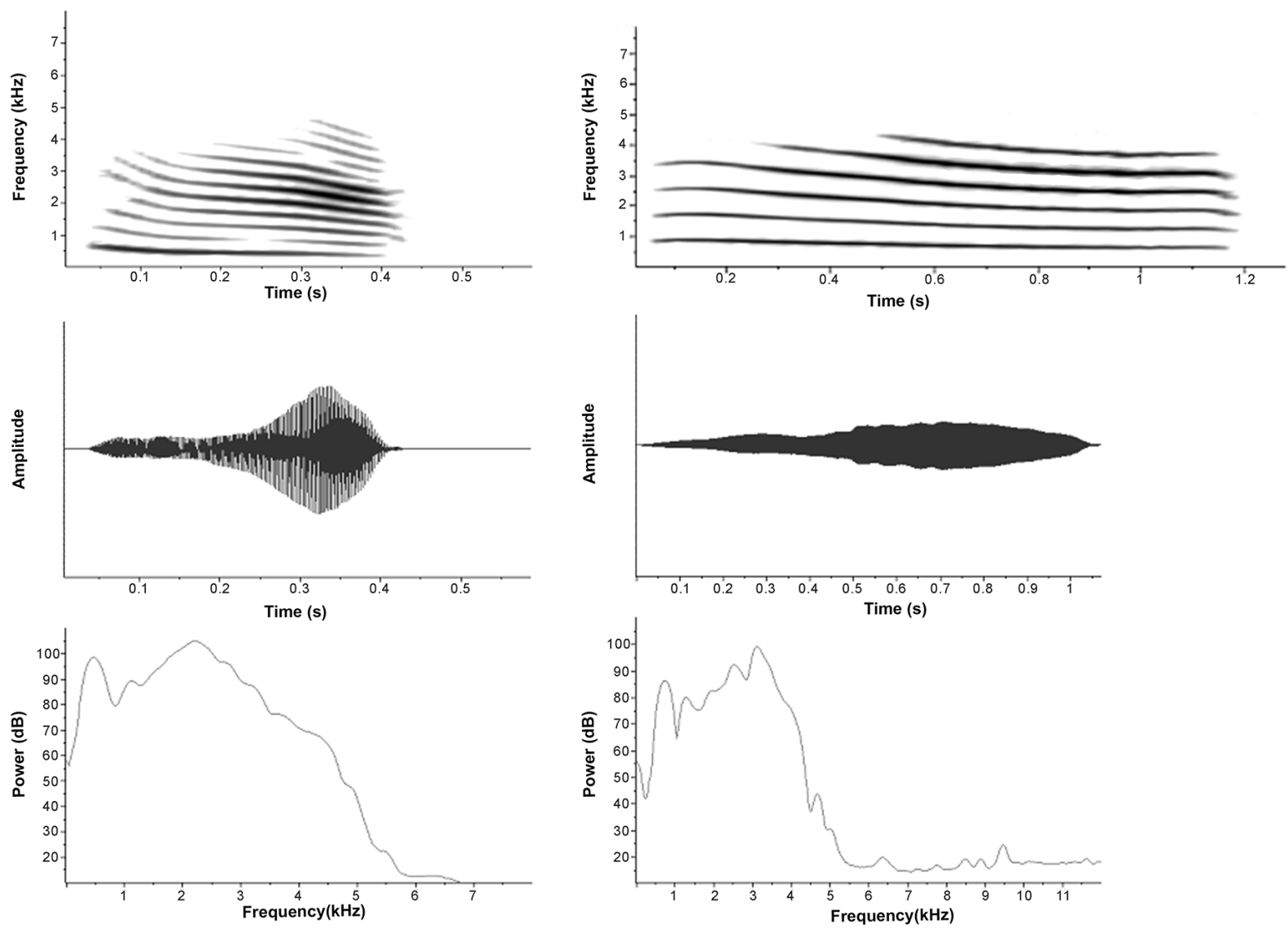

Figure 3. Advertisement calls of $P$. santafecinus (left) and $P$. aff. albonotatus (right) with spectrograms (upper), oscillograms (middle), and power spectrum (low). 
Page 9

\section{Reads:}
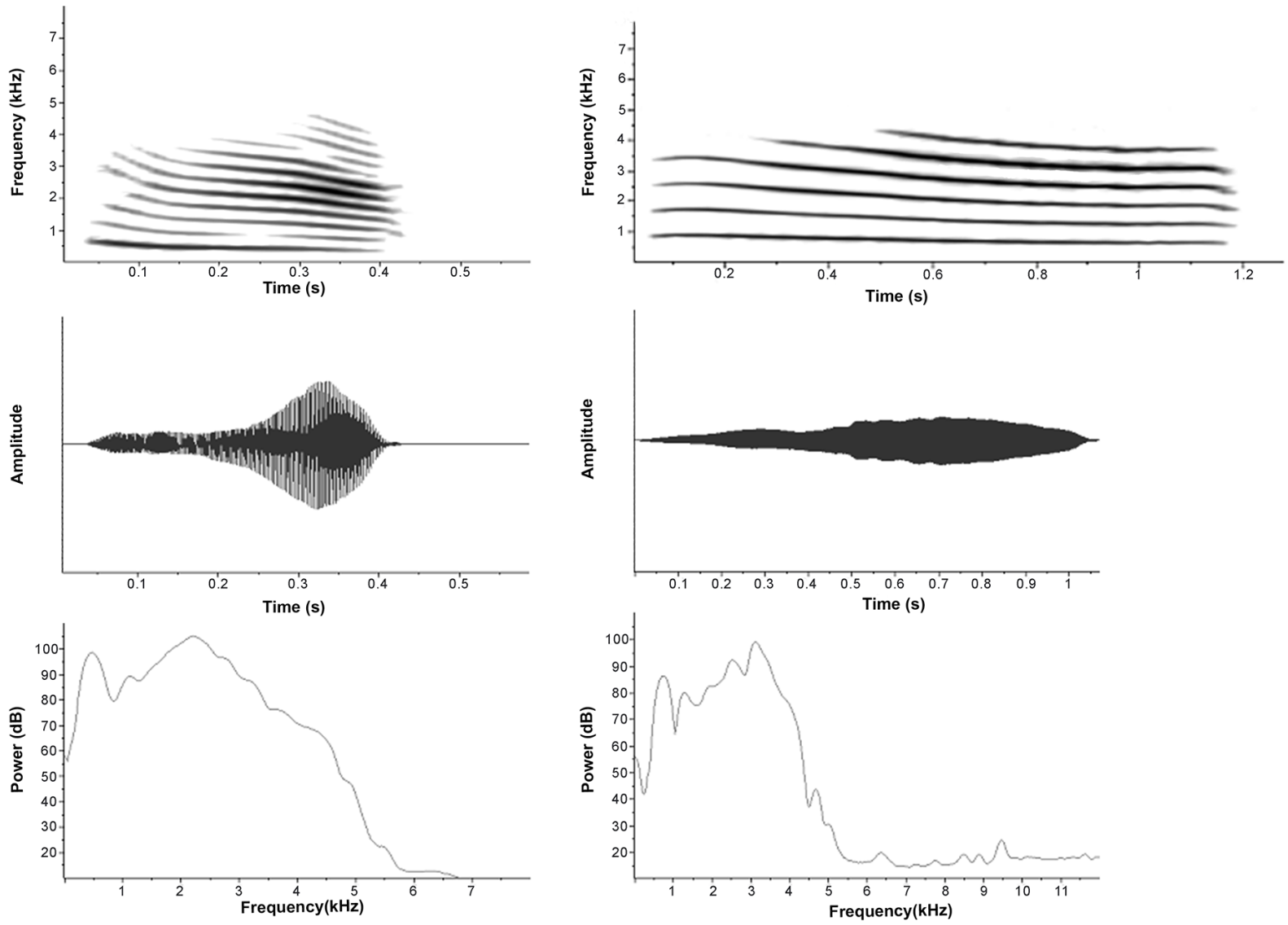

Figure 4. Power spectrum of the first third (left) and the final third (right) of an advertisement call of $P$. aff. albonotatus (above) and P. santafecinus (below). 


\section{Should read:}
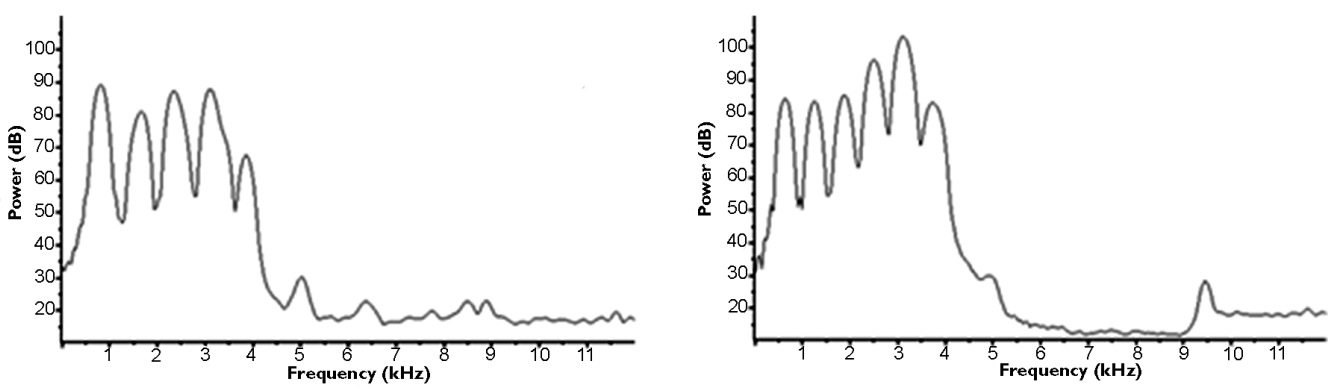

Figure 4. Power spectrum of the first third (left) and the final third (right) of an advertisement call of $P$. aff. albonotatus (above) and $P$. santafecinus
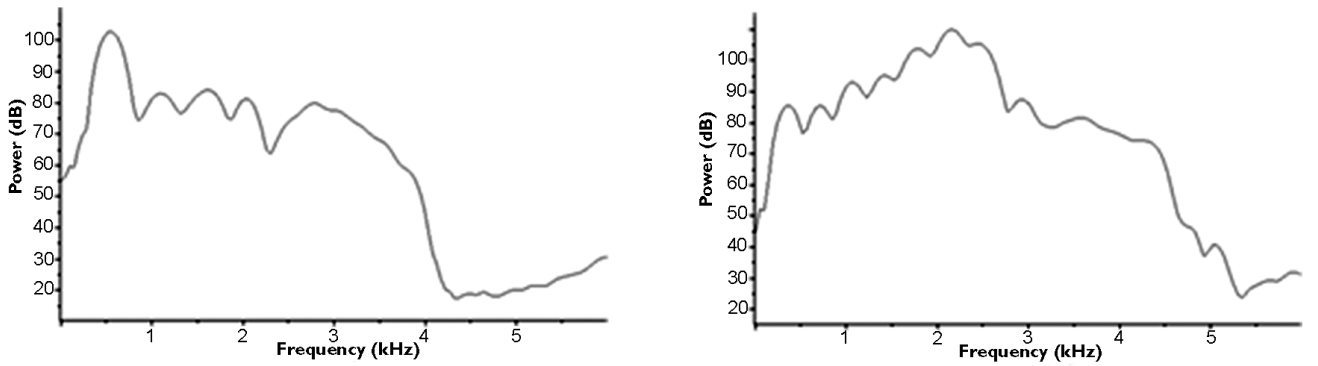

Page 16, column 2, "How to cite" line 1

\section{Reads:}

PIETRO DO

Should read:

DI PIETRO DO

Line 11:

Reads:

DIEGO O. PIETRO 3

Should read:

DIEGO O. DI PIETRO

An Acad Bras Cienc (2021) 93(1): e20180773e

\section{(cc) BY}

